\title{
ANALISIS YURIDIS PERCERAIAN LUAR PENGADILAN DI DESA NYORMANIS KECAMATAN BLEGA KABUPATEN BANGKALAN MADURA
}

\author{
Adinda Dian Eka Saputri, Kurnia Dwi Putri, Nurul Firdausi, \\ Luthfia Chairun Nisa
}

Kurnia Learning Club Jl. Makmur No. 41 Betro Sedati Sidoarjo. Email: kurniadwiputri02@gmail.com

\begin{abstract}
Law in Indonesian has regulated the procedures for marriage, divorce, and reconciliation in Law No. 1 of 1974 concerning Marriage. And also stated in Law No. 22 of 1946 concerning the Recording of Divorce and Referrals. From the explanation contained in the positive law, it can be seen that the meaning of divorce is the breaking of the marriage ties of a married couple as a result of the failure to carry out the marriage due to several things such as death and court decisions. Divorce in law of Indonesian must be announced before the court. The pronouncement of divorce before the court is a mandate from article 115 of the Compilation of Islamic Law (KHI) which reads "Divorce can only be conducted in front of a Religious Court hearing after the Religious Court has tried and failed to reconcile the two parties." But in fact, there are still many Indonesian people who do divorce not before the court. Divorce which is done outside the court is very negative, especially for the wife. Divorce is done only by word alone without going through a pledge in front of the court, then the state does not want to recognize the divorce, so that if the wife wants to remarry with another person, then it cannot be done because the wife does not have an official divorce certificate from the court.
\end{abstract}

Keywords: juridical, divorce outside the court

Abstrak: Hukum Indonesia telah mengatur mengenai tata cara perkawinan, talak, maupun rujuk dalam Undang- Undang No. 1 Tahun 1974 Tentang Perkawinan. Serta tertera pula pada Undang-Undang No. 22 Tahun 1946 Tentang Pencatatan Talak dan Rujuk. Dari penjelasan yang termuat dalam hukum positif tersebut, dapat diketahui bahwa arti perceraian adalah putusnya ikatan pernikahan pasangan suami isteri sebagai akibat kegagalan menjalankan bahterah rumah tangga yang disebabkan oleh beberapa hal seperti kematian dan atas keputusan pengadilan. Perceraian dalam hukum Indonesia, harus diikrarkan di depan pengadilan. Pengucapan talak di hadapan pengadilan merupakan amanah dari pasal 115 Kompilasi Hukum Islam (KHI) yang berbunyi “ Perceraian hanya dapat dilakukan di depan sidang Pengadilan Agama setelah Pengadilan Agama tersebut berusaha dan tidakberhasil mendamaikan kedua belah pihak." Akan tetapi dalam kenyataannya, masih banyak

AL-HUKAMA

The Indonesian Journal of Islamic Family Law

Volume 09, Nomor 02, Desember 2019; ISSN:2089-7480 
masyarakat Indonesia yang melakukan perceraian tidak di depan pengadilan. Perceraian yang diakukan di luar pengadilan sangat lah berdampak negatif, khususnya bagi isteri. Perceraian yang dilakukan hanya secara ucapan saja tanpa melalui ikrar di depan pengadilan, maka negara tidak mau mengakui peceraian tersebut, sehingga apabila si isteri ingin menikah lagi dengan orang lain, maka tidak bisa dilakukan karena isteri tidak memiliki akta perceraian secara resmi dari pengadilan.

Kata kunci: yuridis, perceraian di luar pengadilan.

\section{Pendahuluan}

Perceraian sudah menjadi suatu perkara yang progresif dan mampu merusak tatanan keluarga dalam perkawinan. Kalau kita mengintip perkara-perkara yang ditangani oleh PA (Pengadilan Agama), perkara perceraian menempati urutan pertama, baik itu dari perkara yang diajukan secara cerai talak (dimana si suami yang mengajukan perkara perceraian) maupun gugat cerai (pihak istri yang menuntut perceraian kepada pihak suami). Penyebab perkara perceraian yang ditangani oleh Hakim PA, cukup beragam, sehingga angka perkara perceraian dalam tiap tahunnya terus meningkat.1

Pada saat pasangan akan melakukan perceraian atau dalam proses perselisihan pasangan suami- istri, Islam mengajarkan agar dikirim hakam (seseorang yang mempunyai wewenang) yang bertugas untuk mendamaikan keduanya. Dengan demikian, Islam lebih menganjurkan untuk melakukan perbaikan hubungan suamiistri dari pada memisahkan keduanya.

Dalam konteks hukum positif di Indonesia, prosedur perceraian juga diatur dalam proses yang terdaftar. Selain proses pendamaian, sebagaimana didasarkan pada hukum Islam, untuk melakukan perceraian harus ada cukup alasan, bahwa antara suamiistri itu tidak akan dapat hidup rukun sebagai suami istri.2 Setelah adanya alasan- alasan yang sesuai, tidak berarti perceraian langsung dapat dilakukan oleh pasangan suami- istri. Langkah berikutnya adalah pelaksanaan proses perceraian di depan Pengadilan Agama. Hal ini sebagaimana dijelaskan dalam Undang- Undang Peradilan Agama No. 50 Tahun 2009 yaitu: Perceraian hanya dapat dilakukan

1 M.A Tihami dan Sohari Sahrani, Fikih Munakahat, Kajian Fikih Nikab Lengkap, (Jakarta: Rajawali Pers, 2009), 15.

2 Pasal 39 ayat Undang-undang No. 1 Tahun 1974 tentang Perkawinan 
di depan sidang Pengadilan setelah Pengadilan yang bersangkutan berusaha dan tidak berhasil mendamaikan kedua belah pihak.3

Sebagaimana yang dimaksud dalam Kompilasi Hukum Islam tata cara perceraian juga diatur dalam Pasal 129 yang berbunyi: Seorang suami yang menjatuhkan talak kepada istrinya mengajukan permohonan baik lisan maupun tertulis kepada Pengadilan Agama yang mewilayahi tempat istri disertai dengan alasan serta meminta agar diadakan sidang untuk perkara tersebut.4

Penerapan adanya penjatuhan talak yang harus diikrarkan di depan pengadilan sesuai ketentuan perundang- undnagan yang berlaku. Namun, hal ini berbeda kenyataannya masih terdapat beberapa orang pada Desa Nyormanis Kecamatan Blega Kabupaten Bangkalan yang melakukan perceraian tanpa didepan pengadilan. Ketika suami menginginkan untuk mentalak isterinya karena sebab tertentu, yang kedua pasangan memang tidak bisa meneruskan perkawinan dan sudahberusahan didamaikn secara kekeluaragaan tetapi tidak berhasil, sehingga suami ingin mentalak isterinya dan hanya secara lisan atau tanpa melakukan ikrar talak di depan Pengadilan Agama yang berwenang. Setelah suami mentalak isterinya hanya melalui lisan dan sekadar diketahui oleh keluarganya saja, dimana si suami tersebut tidak perlu mendatangi Pengadilan Agama dan mengucapkan ikrar talak. Karena, menurut suami atau pemahaman penduduk setempat, pengucapan lafad talak secara lisan yang memang diniatkan untuk berpisah dalam Islam sudah dianggap jatuh talak.

Setelah mengucapkan ucapan talak kepada isterinya si suami ini memisahkan ranjang lalu meninggalkan isterinya yang sudah ditalak tersebut untuk bekerja diluar Madura dan tidak diketahui keberadaannya. Sehingga, tiga tahun kemudian si isteri ini menikah lagi dengan duda yang sudah bercerai secara sah di Pengadilan Agama dan juga sudah memiliki akta cerai. Namun, ketika pasangan janda duda ini menikah, mereka menikah secara sirri yakni tidak melalui pencatatan nikah, dikarenkan status isteri yang masih menggantung dan Negara belum menerima status isteri yang ditalak

3 Undang- undang No. 50 Tahun 2009 tentang Peradilan Agama.

4 Tim Redaksi Nuansa Aulia, Kompilasi Hukum Islam, (Bandung: Nuansa Aulia, 2008), 29. 
di luar Pengadilan. Dari contoh kasus di atas yang terjadi pada pasangan suami isteri di Desa Nyormanis Kecamatan Blega Kabupaten Bangkalan Madura, menjadi latar belakang penlis untuk membahas dan menganlisis kasus tersebut yang dielaborasi dengan perundang- undangan yang berlaku di Indonesia.

\section{Perceraian dalam Hukum Positif}

Perceraian merupakan salah satu sebab putusnya suatu ikatan perkawinan, disamping asas monogami, perceraian mendapatkan tempat tersendiri, karena di dalam masyarakat perkawinan seringkali diakhiri dengan perceraian. Penjelasan umum Undang- undang No. 1 Tahun 1974 Tentang Perkawinan, ditentukan bahwa karena tujuan perkawinan adalah untuk membetuk keluarga yang bahagia, kekal, dan sejahtera maka Undang- undang ini menganut perinsip untuk mempersukar terjadinya perceraian.

Perceraian yang diatur pada Undang- undang ini hanyalah dimungkinkan apabila didasarkan atas alasan tertentu, seperti: antara kedua belah pihak suami isteri tersebut tidak ada kemungkinan untuk hidup rukun sebagai suami isteri, maka hal tersebut perceraian hanyalah merupakan jalan terkahir yang diambil oleh kedua belah pihak tersebut. Prosedur perceraian yang diatur dalam Undangundang ini harus dilakukan di hadapan sidang di pengadilan yang berwenang.

Perceraian disebutkan dalam Pasal 38 Undang-undang No. 1 Tahun 1974 berbunyi: perkawinan dapat putus karena, kematian, perceraian, keputusan pengadilan, dan dilanjut pada Pasal 39, yang berbunyi:

1. Perceraian hanya dapat dilakukan di depan Sidang Pengadilan setelah Pengadilan yang bersangkutan berusaha dan tidak berhasil mendamaikan kedua belah pihak

2. Untuk melakukan perceraian harus ada cukup alasan, bahwa antara suami dan isteri itu tidak dapat hidup rukun sebagai suami isteri

3. Tata cara perceraian di depan sidang pengadilan diatur dalam peraturan perundang-undangan itu sendiri.

Alasan tersebut juga diatur dalam Peraturan Pemerintah No. 9 Tahun 1975 Tentang Pelaksanaan UU No. 1 Tahun 1974 Tentang 
Perkawinan, menyebutkan bahwa perceraian dapat terjadi karena alasan- alasan:

a. Salah satu pihak berbuat zina atau menjadi pemabuk, pemadat, penjudi, dan lain sebagainya yang sukar disembuhkan;

b. Salah satu pihak meninggalkan pihak lain selama 2 (dua) tahun berturut- turut tanpa izin pihak lain dan tanpa alasan yang sah atau karena hal lain di luar kemampuannya;

c. Salah satu pihak mendapatkan hukuman penjara 5 (lima) tahun atau hukuman yang lebih berat setelah perkawinan berlangsung;

d. Salah satu pihak melakukan kekejaman dan penganiayaan berat yang membahayakan pihak yang lain;

e. Salah satu pihak mendapat cacat badan atau penyakit yang mengakibatkan tidak dapat melakukan kewajibannya sebagai suami isteri;

f. Antara suami isteri terus menerus terjadi perselisihan dan pertengkaran, dan tidak ada harapan akan hidup rukun dalam rumah tangga.

Dalam Kompilasi Hukum Islam Pasal 113 yang menyebutkan putusnya perkawinan dapat terjadi karena:

a. Kematian

b. Perceraian

c. Atas putusan pengadilan

Dalam Pasal 114 menyebutkan bahwa putusnya perkawinan yang disebabkan karena perceraian dapat terjadi karena talak atau berdasarkan gugatan perceraian. Adapun perceraian merupakan pemutusan ikatan pernikahan terhadap pasangan suami isteri sebagai akibat dari kegagalan dalam menjalankan bahtera rumah tangga yang disebabkan oleh beberapa hal seperti kematian dan atas keputusan pengadilan. Dalam hal ini perceraian dilihat sebagai akhir dari suatu ketidakstabilan perkawinan dimana pasangan suami isteri kemudian hidup terpisah dan secara resmi diakui oleh hukum yang berlaku.

Perceraian menurut bahasa berasal dari kata dasar cerai yang berarti pisah, kemudian mendapat awalan per- yang berfungsi pembentuk kata benda abstrak kemudian menjadi perceraian yang 
berarti hasil dari perbuatan cerai. Sedangkan pengertian talak menurut istilah adalah menghilangkan ikatan pernikahan atau mengurangi pelepasan ikatan dengan menggunakan kata-kata tertentu.5

Perceraian menurut Kamus Besar Bahasa Indonesia (KBBI) berasal dari kata cerai, yang berarti pisah, putus hubungan sebagai suami istri.6 Menurut pokok-pokok hukum perdata bahwa perceraian adalah penghapusan perkawinan dengan putusan hakim atau tuntutan salah satu pihak dalam perkawinan.7

\section{Macam-Macam Perceraian}

1. Talak raj'i

Pasal 118 dalam Kompilasi Hukum Islam (KHI) menyebutkan bahwa talak raji adalah talak kesatu atau kedua, dalam talak ini suami berhak rujuk selama isteri dalam masa iddah. Setelah terjadi talak raj'i maka isteri wajib beriddah, hanya bila kemudian mantan suami hendak kembali kepada mantan isterinya sebelum berakhir masa iddah. Maka itu dapat dilakukan dengan menyatakan rujuk. Tetapi jika dalam masa iddah tersebut mantan suami tidak menyatakan rujuk terhadap mantan isterinya, maka dengan berakhirnya masa iddah tersebut kedudukan talak menjadi talak ba'in. kemudian sesudah berakhirnya masa iddah itu, suami ingin kembali kepada mantan isterinya maka wajib melakukan dengan akad baru dan dengan mahar pula. 8

2. Talak Ba'in

Talak ba'in adalah talak yang tidak memberi hak berujuk bagi mantan suami terhadap mantan isterinya. Untuk mengembalikan mantan isteri kedalam ikatan perkawinan dengan mantan suami harus melalui akad nikah baru, lengkap dengan rukun dan syaratsyaratnya. 9

Talak ba'in terdapat dua macam yaitu:

a. Talak ba'in shugra

5 Sayyid Sabiq, Fiqh al-Sunnah,(Kairo: Maktabah dar al-Turas, tth),278

6 Departemen Pendidikan dan Kebudayaan, Kamus Besar Babasa Indonesia, 164.

7 Subekti, Pokok- pokok Hukum Perdata, (Jakarta: PT. Intermasa, 2010), 42.

8 Abdul Rahman Gazaly, Fikih Munakahat, (Premena Jaya, 2006). 191

9 Ibid., 198 
Talak ba'in shugra adalah talak ba'in yang menghilangkan pemilikan mantan suami terhadap isteri tetapi tidak menghilangkan kehalalan mantan suami untuk kawin kembali dengan mantan isteri, baik dalam masa iddahnya maupun sesudah berakhirnya masa iddah.

b. Talak ba'in qubra

Talak ba'in qubra adalah talak yang menghilangkan pemilikan mantan suami terhadap mantan isteri serta menghilangkan kehalalan mantan suami untuk berkawin kembali dengan mantan isterinya. Kecuali setelah mantan isteri itu kawin dengan laki-laki lain telah berkumpul dengan suami keduanya itu serta telah bercerai secara wajar serta selesai menjalankan masa iddahnya. Talak bai'in qubra terjadi pada talak yang ke tiga.

c. Talak sunni

Talak sunni adalah talak yang di perbolehkan untuk dijatuhkan kepada isteri, yaitu talak dijatuhkan kepada isteri yang dalam keadaan suci serta tidak dicampuri.10

d. Talak Bid'i

Talak bid'i adalah larangan menjatuhkan talak kepada isteri yang dalam keadaan haid atau suci tetapi setelah digauli dan nifas. Bila diperinci terdiri dari beberapa macam:11

1) Apabila seorang suami menceraikan isterinya ketika sedang dalam keadaan haid atau nifas.

2) Jika seorang suami menceraikan isterinya ketika dalam keadaan suci, namun ia telah menyetubuhinya pada masa suci tersebut.

3) Seorang suami telah menjatuhkan talak tiga kepada isterinya dalam satu kalimat atau tiga kalimat dalam satu waktu.

10 Syaikh Hasan, Fikih Keluarga, (Jakarta: Pustaka al-Kautsar, 2006), 211

11 Munandar, Skripsi: "Tinjanan Hukum Islam Terbadap Talak Di Luar Pengadilan Agama Pada Masyarakat Di Kecamatan Lappariaja Kabupaten Bone" (Makassar: UIN Alauddin Makassar, 2017), 24 


\section{Prosedur Perceraian}

Prosedur perceraian diatur dalam Kompilasi Hukum Islam pada pasal 129 sampai pasal 148. Pasal tersebut memuat prosedur perceraian berdasarkan dua bentuk perceraian yang diatur dalam hukum acara Pengadilan Agama yaitu cerai talak dan cerai gugat.

1. Cerai talak yaitu sebagaimana pengertian talak dalam hukum Islam yaitu talak yang dijatuhkan oleh suami kepada isteri

2. Cerai gugat yaitu suatu gugatan yang diajukan oleh isteri terhadap suami kepada Pengadilan dengan alasan-alasan tertentu

Pasal 129 sampai $131 \mathrm{KHI}$ mengatur tentang prosedur cerai talak di Pengadilan Agama yang dijatuhkan oleh suami kepada isterinya harus berdasarkan beberapa prosedur yaitu: 12

1. Seorang suami yang akan menjatuhkan talak kepada isterinya mengajukan permohonan secara lisan atau tertulis kepada Pengadilan Agama yang mewilayahi tempat tinggal isteri dengan alasan perceraian.

2. Pengadilan Agama dapat mengabulkan atau menolak permohonan tersebut dan terhadap putusan tersebut dapat diajukan banding atau kasasi

3. Pengadilan yang bersangkutan mempelajari permohonan cerai selambat-lambatnya 30 hari untuk memanggil pemohon dan isterinya dengan dimintai penjelasan mengenai segala sesuatu yang berhubungan dengan maksud menjatuhkan talak

4. Setelah Pengadilan Agama tidak berhasil menasehati kedua belah pihak dan ternyata cukup alasan sang suami untuk menjatuhkan talak maka Pengadilan Agama dapat menjatuhkan keputusan tentang izin bagi suami untuk mengikrarkan talak

5. Setelah keputusan Pengadilan Agama mempunyai hukum tetap, suami mengikrarkan talaknya di depan sidang di hadiri oleh isteri atau kuasanya

6. Apabila suami tidak mengucapkan ikrar dalam tempo 6 bulan terhitung sejak putusan, maka hak suami untuk

12Kompilasi Hukum islam, Pasal 129-131. 
mengucapkan ikrar talak gugur dan ikatan perkawinan tetap utuh

7. Setelah sidang penyaksian ikrar talak Pengadilan Agama membuat penetapan Tentang talak rangkap empat yang merupakan bukti perceraian bagi bekas suami dan isteri. Helai pertama beserta surat ikrar talak dikirimkan ke PPN yang mewilayahi tempat tinggal suami untuk diadakan pencatatan, helai kedua dan ketiga masing-masing diberikan kepada suami dan isteri, sedangkan helai keempat disimpan di Pengadilan Agama.

Pada pasal 132-148 dalam KHI dijelaskan tentang prosedur cerai gugat sebagai berikut:

1. Isteri atau kuasanya mengajukan cerai gugat pada pengadilan Agama yang mewilayahi daerah hukum penggugat. Jika tergugat berapa diluar Negeri maka Pengadilan Agama menyampaikan melalui perwakilan RI setempat

2. Pemeriksaan gugatan perceraian dilakukan oleh hakim selambat-lambatnya 30 hari.

3. Pada sidang pemeriksaan gugatan suami isteri datang sendiri atau diwakili oleh kuasa hukumnya. Namun untuk kepentingan pemeriksaan, hakim dapat memanggil yang bersangkutan hadir sendiri.

4. Mediasi yang dilakukan oleh hakim dan selama perkara belum di putuskan, maka usaha perdamaian dapat dilakukan setiap kali sidang

5. Putusan mengenai gugatan perceraian dilakukan dalam sidang terbuka. Perceraian dianggap terjadi beserta akibatakibatnya terhitung sejak jatuhnya putusan Pengadilan yang mempunyai kekuatan hukum tetap

6. Setelah diputus perceraian maka Pengadilan Agama menyampaikan salinan putusan kepada suami isteri atau kuasanya dengan menarik kutipan akta nikah dari kedua belah pihak. Untuk selanjutnya panitera Pengadilan Agama mengirimkan satu helai salinan putusan kepada PPN yang 
mewilayahi tempat kediaman isteri untuk dicatatkan dan surat keterangan bahwa putusan mempunyai hukum tetap.13

Tata cara perceraian juga diatur dalam pasal 39 sampai dengan pasal 41 Undang-Undang No.1 tahun 1974 dan juga diatur dalam pasal 14 sampai dengan pasal 36 Peraturan Pemerintah No.9 tahun 1975. Bagi warga Negara yang beragama Islam diatur dalam pasal 26 sampai dengan pasal 31 PMA No.3 tahun 1975 dan pasal 66 sampai 88 Undang-Undang No.7 tahun 1989 tentang Peradilan Agama.

Prosedur perceraian dengan cara talak diatur pada pasal 14 sampai dengan pasal 18 Peraturan Pemerintah Nomor 9 Tahun 1975, yaitu berlaku bagi mereka yang menganut agama Islam. Dalam pasal 14 Peraturan Pemerintah tersebut berbunyi: Seorang suami yang telah melangsungkan perkawinan menurut agama Islam yang akan menceraikan isterinya mengajukan surat kepada pengadilan di tempat tinggalnya, yang berisikan pemberitahuan, bahwa ia bermaksud menceraikan isterinya, disertai dengan alasan- alasan serta meminta kepada pengadilan agar diadakan sidang untuk keperluan itu. Menurut ketentuan tersebut yang dapat memenuhi prosedur ini adalah seorang suami dan beragama Islam, sedangkan bagi isteri yang beragama Islam, Undang- undang No. 1 Tahun 1974 Tentang Perkawinan menentukan prosedur yang lain. Selanjutnya menurut peraturan ini si suami tersebut menyampaikan surat pemberitahuan kepada pengadilan, bahwa suami akan mencerikan isterinya dan untuk itu si suami meminta supaya pengadilan mengadakan sidang untuk menyaksikan perceraian itu, sehingga yang diajukan oleh suami itu bukan permohonan supaya pengadilan memutuskan perceraian. Pemberitahuan itu diajukan oleh suami secara tertulis.

Dalam hal terjadinya perceraian dalam sidang pengadilan, maka Ketua Pengadilan membuat surat keterangan tentang terjadinya perceraian, jadi bukan keputusan pengadilan. Menurut pasal 15, setelah pengadilan menerima surat pemberitahuan itu, pengadilan mempelajari surat tersebut dan selambat- lambatnya dalam tempo 30 (tiga puluh) hari setelah menerima surat itu pengadilan

13 Ibid., Pasal 132-147 
memanggil suami dan isteri yang akan bercerai itu untuk meminta penjelasan- penjelasan.

Setelah pengadilan mendapatkan penjelasan dari suami isteri dan ternyata memang terdapat alasan- alasan untuk bercerai, dan juga pengadilan berpendapat bahwa antara suami dan isteri yang bersangkutan tidak mungkin lagi didamaikan, pengadilan memutuskan untuk mengadakan sidang perihal penyaksian perceraian itu. 14

Pelaksanaan sidang pengadilan untuk menyaksikan perceraian yang dimaksud dalam pasal 16 Undang-undang No. 1 Tahun 1974 Tentang Perkawinan, Ketua Pengadilan membuat surat keterangan tentang terjadinya perceraian tersebut. Menurut pasal 17 Undangundang No. 1 Tahun 1974 Tentang Perkawinan tersebut surat-surat keterangan itu dikirimkan kepada pegawai pencatat di tempat perceraian itu terjadi untuk diadakan pencatatan perceraian. Selanjutnya pada pasal 18 Undang- undang tersebut bahwa perceraian itu terjadi terhitung pada saat perceraian itu dinyatakan di depan sidang pengadilan.

Sementara perihal perceraian yang diajukan oleh isteri atau yang disebut cerai gugat, pada dasarnya dilakukan oleh isteri dengan alasan- alasan sebagaimana diatur dalam Undang- undang No. 1 Tahun 1974 Tentang Perkawinan. Cerai gugat ini diajukan oleh isteri diwilayah Pengadilan Agama dimana perkawinan berlangsung. Cerai gugat ini pada dasarnya di buat dengan maksud untuk menghindari kesewenang- wenangan suami serta hal- hal lainnya yang memberikan hak bagi isteri untuk mengajukan gugatan cerai.

Penjelasan pasal 20 Undang- undang No. 1 Tahun 1974 Tentang Perkawinan menyatakan gugatan perceraian yang dimaksud dapat dilakukan oleh seorang isteri yang melangsungkan perkawinan menurut agama Islam dan oleh seorang suami atau seorang isteri yang melangsungkan perkawinannya menurut agamanya dan kepercayaanya itu selain agama Islam. Gugatan perceraian diajukan oleh suami atau isteri atau kuasanya kepada pengadilan yang daerah hukumnya meliputi tempat kediaman tergugat. Dalam hal tempat kediaman tergugat tidak jelas atau tidak diketahui atau tidak

14 Vivi Hayati, Dampak Yuridis Perceraian di Luar Pengadilan (Penelitian diKota Langsa), Vol. 10 No. 2 Juli 2015, 219. 
mempunyai tempat kediaman yang tetap, gugatan perceraian diajukan kepada pengadilan di tempat kediaman penggugat. Dalam hal tergugat bertempat kediaman diluar negerigugatan perceraian diajukan kepada tergugat melalui perwakilan Republik Indonesia seperti yang diatur dalam pasal 20 Undang- undang No. 1 Tahun 1974 Tentang Perkawinan.

Gugatan perceraian dalam hal alasan terjadinya perselisihan dan pertengkaran dan tidak ada harapan akan hidup bersama lagi dalam rumah tangga, diajukan kepada pengadilan di tempat kediaman tergugat. Gugatan perceraian, dapat diterima apabila telah cukup jelas bagi pengadilan mengenai sebab- sebab perselisihan dan pertengkaran itu dan setelah mendengar pihak keluarga serta orangorang yang dekat dengan suami isteri itu diatur pada pasal 2 UU No. 1 Tahun 1974 ini. Dalam pasal 23 Undang- undang No. 1 Tahun 1974, ditentukan gugatan perceraian dengan alasan salah seorang dari suami isteri mendapat hukuman penjara 5 (lima) tahun atau hukuman yang lebih berat sebagaimana yang dimaksud dalam pasal 19 huruf c Undnag- undang No. 1 Tahun 1974, maka untuk mendapatkan putusan percerian sebagai bukti penggugat cukup menyampaikan salinan putusan pengadilan yang memutuskan perkara disertai keterangan yang menyatakan bahwa putusan itu telah mempunyai kekuatan hukum yang tetap.

Adapun tatacara perceraian yang diatur dalam pasal 20 sampai dengan 36 Peraturan Pemerintah No.9 tahun 1975, yaitu:

1. Gugatan perceraian diajukan oleh isteri atau kuasanya oleh pengadilan yang daerah hukumnya meliputi tempat kediaman tergugat

2. Dalam hal tempat kediaman tergugat tidak jelas atau tidak mempunyai tempat kediaman yang tetap, maka gugatan perceraian diajukan kepada Pengadilan Agama setempat di daerah tempat tinggal tergugat

3. Apabila penggugat bertempat tinggal diluar Negeri, maka gugatan perceraian diajukan ditempat kediaman penggugat

4. Dalam hal gugatan perceraian dengan salah satu alasan meninggalkan pihak lain selama 2 tahun berturut-turut tanpa izin pihak lain atau tanpa alasan yang sah atau karena hal lain 
diluar kemampuannya, diajukan kepada Pengadilan setempat kediaman penggugat. 15

Selama berlangsungnya gugatan perceraian atau permohonan penggugat atau tergugat atau berdasarkan pertimbangan bahaya yang mungkin di timbulkan, pengadilan dapat mengizinkan suami isteri tersebut tidak tinggal dalam satu rumah, dan selama berlangsungnya gugatan perceraian, atas permohonan penggugat maupun tergugat, maka pengadilan dapat:

1. Menentukan nafkah yang harus ditanggung oleh suami;

2. Menentukan hal- hal yang perlu untuk menjamin pemeliharaan dan pendidikan anak;

3. Menentukan hal- hal yang perlu untuk menjamin terpeliharanya barang- barang yang menjadi hak bersama suami isteri atau barang- barang yang menjadi hak isteri.

\section{Akibat Perceraian}

Hukum Islam maupun peraturan Perundang-undangan di Indonesia menyatakan bahwa perceraian yang terjadi antara seorang suami dan isteri bukan hanya memutuskan ikatan perkawinan saja, lebih lanjut perceraian juga melahirkan beberapa akibat seperti timbulnya pembagian harta bersama (gemenshap) dan hak pengurusan anak (hadanah).

1. Harta Bersama

Perceraian yang timbul antara suami dan isteri melahirkan akibat,diantaranya adalah pembagian harta bersama. Dalam bahasa Belanda disebut gemenschap. Sebenarnya konsep harta bersama dalam hukum Islam tidak ditemukan nash yang secara tegas menyebutkan hukum harta bersama baik dalam al-Qur'an maupun hadis. Karenanya hal ini merupakan ranah ijtihad bagi ulama yang memiliki kapasitas untukmelakukan ijtihad atau yang dikenal dengan istilah mujtahid.

Satria Effendi M. Zein menyebutkan bahwa dalam kultur masyarakat muslim berkaitan dengan harta yang diperoleh dalam sebuah pernikahan ada dua kultur yang berlaku, yang Pertama; kultur masyarakat yang memisahkan antara harta suami dan harta 
isteri dalam sebuah rumah tangga. Dalam masyarakat muslim seperti ini, tidak ditemukan adanya istilah harta bersama. Kedua; masyarakat muslim yang tidak memisahkan harta yang diperoleh suami isteri dalam pernikahan. Masyarakat muslim seperti ini mengenal dan mengakui adanya harta bersama. Di Indonesia, atas dasar adat kebiasaan masyarakat muslim yang mengakui adanya harta bersama setelah terjadinya perceraian sudah menjadi lebih kuat dan berkekuatan hukum positif, sejak diregulasi dan diratifikasi, sebagaimana substansi yang telah dituangkan dalam Pasal 35ayat (1) dan ayat (2) Undang-Undang Nomor 1 tahun 1974 bahwa: 16

a. Harta benda yang diperoleh selama perkawinan menjadi harta bersama

b. Harta bawaan dari masing-masing suami dan isteri dan harta benda yang diperoleh masing-masing sebagai hadiah atau warisan, adalah di bawah penguasaan masingmasing sepanjang para pihak tidak menentukan lain.

Sedangkan dalam hukum Belanda yang terdapat dalam Pasal 119 dan Pasal 126 Burgerlijk Wetboek disebutkan bahwa sejak saat dilangsungkan perkawinan, maka menurut hukum, terjadilah percampuran harta antara suami isteri yang disebut dengan harta bersama. Hal ini terjadi selama tidak ditentukan lain dalam perjanjian perkawinan.

Harta bersama bubar atau berakhir demi hukum disebabkan;kematian salah satu pihak, perceraian, pisah meja dan ranjang dan karena pemisahan harta yang dituangkan dalam perjanjian sebelum terjadinya perkawinan. Dan dalam Pasal 127 Burgerlijk Wetboek, setelah bubarnya harta bersama, kekayaan mereka dibagi dua antara suami dan isteri atau antara para pewaris mereka tanpa mempersoalkan dari pihak mana asal barang-barang itu.

2. Pengurusan Anak

Perceraian disamping menimbulkan adanya pembagian harta bersama seperti yang diterangkan diatas, juga menimbulkan masalah pengurusan anak. Pengurusan anak atau dikenal dengan

16Satria Effendi, Problematika Hukum Keluarga Islam Kontemporer, Jakarta: Kencana. Cet.2), 60-61. 
sebutan hadlonah. Hukum Islam menyebutkan bahwa apabila terjadi perceraian antara suami dan isteri, maka isterilah yang berhak mengasuh mendidik dan memelihara anak-anaknya selama anak-nya belum mumayyiz. Hal ini berdasarkan Sabda Rasulullah SAW kepada seorang isteri yang mengadukan pengurusan anaknya setelah isteri tersebut bercerai dari suaminya. Nabi SAW bersabda:'Kaulah yang lebih berbak mendidik anakmu selama kamu belum kawin dengan orang lain". (Hadits riwayat Abu Dawnd dan al-Hakim).”17

Disamping dua akibat perceraian di atas, akibat putusnya perkawinan karena perceraian, terhadap pengurusan anak terdapat dalam Pasal 41 Undang-Undang Nomor 1 Tahun 1974 tentang Perkawinan yang menyebutkan:

a. Baik ibu atau bapak tetap berkewajiban memelihara danmendidik anak-anaknya, semata-mata berdasarkan kepentingan anak; bilamana ada perselisihan mengenai penguasaan anak-anak, Pengadilan memberi keputusannya;

b. Bapak yang bertanggung-jawab atas semua biaya pemeliharaan dan pendidikan yang diperlukan anak itu; bilamana bapak dalam kenyataan tidak dapat memenuhi kewajiban tersebut, Pengadilan dapat menentukan bahwa ibu ikut memikul biaya tersebut; Pengadilan dapat mewajibkan kepada bekas suami untuk memberikan biaya penghidupan dan/atau menentukan sesuatukewajiban bagi bekas isteri.

\section{Profil Desa Nyormanis Kecamatan Blega Kabupaten Bangkalan Madura}

1. Kondisi Geografis

Kabupaten Bangkalan berada pada bagian sebelah barat Pulau Madura, terletak pada koordinat $112^{\circ} 40^{\prime} 6-113^{\circ} 08^{\prime} 04$ Bujur Timur serta $6^{\circ} 51^{\prime} 39-7^{\circ} 11^{\prime} 39$ Lintang Selatan. Kabupaten Bangkalan memiliki luas 1.260,14 $\mathrm{Km}^{2}$ terbagi menjadi 18

17Satria Effendi, Problematika Hukum Keluarga Islam Kontemporer, Jakarta: Gramedia, 2004), 62. 
Kecamatan, 273 Desa dan 8 Kelurahan. Untuk memudahkan pemahaman penjelasan di atas, berikut ini tabel penjelasan luas masing-masing kecamatan tersebut. Sedangkan batas administrasi wilayah Kabupaten Bangkalan adalah sebagai berikut:

a. Sebelah Utara : Laut Jawa

b. Sebelah Timur : Kabupaten Sampang

c. Sebelah Selatan: Selat Madura

d. Sebelah Barat : Selat Madura18

Desa Nyormanis merupakan salah satu desa yang berada di Kecamatan Blega. Desa Nyormanis mempunyai luas wilayah $1.097 \mathrm{Ha}$ dan jumlah penduduk mencapai 2.534 jiwa.Mayoritas mata pencaharian masyarakat di Desa Nyormanis merupakan seorang petani dan pedagang. Selain itu, masyarakat Desa Nyormanis dalam kehidupan sosialnya terkenal dengan masyarakat yang religius.

Implementasi nilai keagamaan di Desa Nyormanis sendiri sangat beragam. Salah satu implementasi tersebut yakni dengan adanya kegiatan tahlilah yang diadakan rutin setiap minggunya serta dipimpin langsung oleh para pemuka agama di desa tersebut. Di Desa Nyormanis masyarakat lebih menghormati dan mempercayai pemuka agama (Kiai) dibandingkan dengan perangkat desa seperti Kepala Desa19.

Selain agama, masyarakat di Desa Nyormanis juga kentaldenganadat-istiadatnya. Masyarakat Desa Nyormanistidak pernah meninggalkan adat-istiadat mereka yang telah ada sejak dahulu kala. Dalam pemahaman perkawinan, mereka mengutamakan keabsahan dari sisi sah atau tidaknya menurut pandangan agama.20

2. Kehidupan Sosial

18 Peta Wilayah Administrasi Kabupaten Bangkalan (Rencana Pembangunan Jangka Menengah Daerah Kabupaten Bangkalan Tahun 2013-2018, II-2) ${ }_{19}$ Wawancara dengan Bapak Salahuddin, selaku sesepuh Desa Nyormanis, pada tanggal 1 oktober 2019 pukul 13.00 WIB.

20 Ibid 
Masyarakat di Desa Nyormanis dalam hal bersosialisasi selalu bergotong royong. Terbukti dengan diadakannya kerja bakti yang rutin mereka laksanakan dalam dua minggu sekali. Kegiatan tersebut dapat menjadikan hubungan antar warga Desa Nyormanis semakin erat. Selain itu, mereka juga ramah tamah. Dapat dilihat ketika ada seseorang yang datang dari luar desa, mereka menyambutnya dengan baik. Dalam hal kearifan tersebut, tentunya tidak hanya satu atau dua orang saja, akan tetapi rata - rata masyarakat di desa itu sangat bersifat sedemikian. Terbukti saat saya di antar oleh bapak kepala Desa Nyormanis untuk berkunjung dan memastikan tentang pernikahan talak di luar pengadilan yang memang cukup marak dilaksanakan di tempat tersebut21

3. Kehidupan Ekonomi

Dalam memenuhi kebutuhan hidupnya warga Desa Nyormanis tentu tidak jauh berbeda dengan masyarakat pedesaan pada umumnya, yakni dengan menggunakan pertanian subsistem dimana pertanian tersubut merupakan pertanian dalam skala kecil untuk bertahan hidup dan memenuhi kebutuhan sehari-hari. Diantara beberapa tanaman-tanaman yang ditanam oleh petani warga Desa Nyormanis adalah singkong, jagung dan tembakau. Terutama jagung dan singkong yang menjadi pangan paling menunjang di Desa ini. Tidak hanya itu, peternakan sapi kecil - kecilan juga menjadi salah satu penunjang ekonomi masyarakat Desa Tersebut meskipun tidak semuanya memiliki peternakan sapi. juga terdapat setidaknya tiga orang yang bekerja menjadi pegawai negeri sipil22

4. Pendidikan

Dalam pendidikan masyarakat Desa Nyormanis tentunya juga sudah mendapatkan Pendidikan yang semestinya, terbukti dengan banyaknya warga masyarakat desa nyormanis yang sudah bersekolah ke jenjang Pendidikan yang lebih tinggi, seperti menempuh pendidikan di perguruan tinggi negeri maupun

21 Wawancara dengan Bapak Aji Suprapto, selaku Kepala Desa Nyormanis, pada tanggal 1 oktober 2019 pukul 10.00 WIB.

22 Ibid 
swasta lainya. Meskipun rata - rata dari orang tua meraka berlatar pendidikan yang rendah yakni Sekolah Dasar atau masih Sekolah rakyat dan bahkan hanya sebagai petani maupun pedagang saja23.

5. Kehidupan Keagamaan

Dalam urusan beribadah masyarakat Desa Nyormanis hampir seluruhnya beragama Islam dan merupakan masyarakat muslim yang taat. Ketika adzan di kumandangkan mereka segera meninggalkan pekerjaannya dan bergegas menuju masjid untuk melaksakan sholat berjamaah. Setiap minggunya juga diadakan tahlilan rutin antar rumah di desa tersebut. Satu tahun sekali rata -rata masyarakat desa tersebut berkurban ketika idul adha yang menandakan bahwa dalam ranah agama mereka adalah masyarakat yang taat terhadap Tuhannya24.

\section{Pandangan masyarakat Desa Nyormanis Kecamatan Blega Kabupaten Bangkalan Madura}

Pada dasarnya, masyarakat Desa Nyormanis rata-rata menganggap bahwa perceraian cukup dilakukan secara lisan dan dianggap sah serta dengan dampak-dampak yang ditimbulkannya. Setelah adanya perceraian secara lisan, seorang suami yang sudah menceraikan secara lisan biasanya langsung memisahkan diri, pergi dari rumah, dan tidak berada di lingkungan isterinya yang sudah ditalak tersebut, biasanya sisuami yang mentalak secara lisan tersebut hanya memberikan kabar kepada keluarganya dan tidak memberikan kabar kepada isterinya maupun anaknya yang lahir dari pernikahan yang sah dan sudah tercatat tersebut. Kemudian, tidak jarang dari pasangan yang telah bercerai tersebut kemudian melakukan perkawinan berikutnya dengan orang lain tanpa melalui KUA (Nikah Sirih) nikah yang tanpa dicatatkan. Hal tersebut tidak lain karena keyakinan masyarakat bahwa perceraian yang mereka lakukan adalah benar secara agama dan dilakukan dihadapan Sang Kyai dimana Kyai tersebut menduduki strata sosial yang tinggi dimasyarakat itu. Mereka sangat percaya kepada tokoh agama dan beranggapan bahwa tidak ada akibat hukum lain yang ditimbulkan

23 Wawancara dengan Bapak Aji Suprapto, selaku Kepala Desa Nyormanis, pada tanggal 1 oktober 2019 pukul 10.00 WIB.

24 Ibid 
setelah proses perceraian tanpa ikrar talak dipengadilan lalu menikah dengan tidak dicatatkan tersebut.

Masyarakat di desa Nyormanis Kecamatan Blega Kabupaten Bangkalan Madura masih memiliki anggapan bahwasanya apabila mereka berurusan dengan pengadilan maka prosesnya sangat sulit dan memakan waktu yang tentunya tidak sedikit. Mereka juga beranggapan bahwasannya biaya yang akan dikeluarkan pun tidak sedikit. Masyarakat di sana juga masih lebih memilih sesuai ajaran agama Islam dibandingkan dengan peraturan yang berlaku di Indonesia.

Adapun mengenai perceraian dalam pandangan mereka itu sah apabila dilakukan sesuai dengan ajaran agama Islam. Asalkan itu sudah memenuhi syarat sesuai dengan ketetapan dalam agama islam, mereka menganggap itu sudah cukup menyatakan bahwasanya hubungan suami istri diantara keduanya sudah putus. Hal tersebut tidak lain karena keyakinan masyarakat bahwa perceraian yang mereka lakukan adalah benar secara agama dan dilakukan dihadapan Sang Kyai dimana Kyai tersebut menduduki strata sosial yang tinggi pada masyarakat itu. Mereka sangat percaya kepada tokoh agama dan beranggapan bahwa tidak ada akibat hukum lain yang ditimbulkan setelah proses perceraian tanpa ikrar talak di pengadilan lalu menikah dengan tidak dicatatkan tersebut. Apabila mereka ingin menjalin hubungan dengan orang lain maka diperbolehkan.

Menurut Sumiati (Nasumber yang ditalak oleh suaminya tanpa diikrarkan di depan pengadilan) pernikahannya yang kedua ini tidak bisa di catatkan di kantor urusan agama. Menurut penjelasan pegawai kantor urusan agama alasan kenapa tidak bisa di catatkan adalah karena tidak mempunyai akta perceraian yang diterbitkan dari putusan pengadilan. Untuk mengurus surat perceraian di pengadilan membutuhkan proses yang tidak sebentar, juga dibutuhkan biaya yang mahal. Susahnya persyaratan dan administrasi di pengadilan serta jarak dari pengadilan yang jauh dari rumah tempat tinggalnya membuat enggan mengurus akta perceraian tersebut. Ditambah lagi suami yang pertama sudah menghilang semenjak menjatuhkan ikrar talak.

\section{Analisis terhadap Talak di Luar Pengadilan di Desa Nyormanis Kecamatan Blega Kabupaten Bangkalan Madura}


Permasalahan mengenai perceraian yang seharusnya dilakukan di hadapan pengadilan Agama adalah sebuah keharusan menurut pasal 38 UU No. 1 tahun 1974 dan pasal 114 KHI. Sedangkan terdapat kasus yang terjadi di Desa Nyormani Kecamatan Blega Kabupaten Bangkalan yang melakukan perceraian hanya dilakukan dengan pengucapan ikrar dari suami tanpa di hadapan Pengadilan Agama.

Penulis meneliti kondisi salah satu masyarakat yang berada di Desa Nyormanis Kecamatan Blega Kabupaten Bangkalan Madura yang melakukan ikrar talak di luar pengadilan. Kondisi yang dimaksud disini yakni bagaimana masyarakat melakukan ikrar tersebut, dilihat dari segi usia pernikahan, cara melakukan talak dan hak-hak yang terpenuhi atau tidak setelah terjadinya talak tersebut.

Mengenai talak di luar Pengadilan Agama yang di lakukan oleh masyarakat Desa Nyormanis, tidak terlepas dari adat-istiadat yang sudah lama dianut masyarakat Desa Nyormanis, dan ada beberapa faktor yang menyebabkan masyarakat Desa Nyormanis melakukan talak di luar Pengadilan Agama.Faktor-faktor tersebut yakni adat, biaya, lokasi Pengadilan Agama dan kurangnya kesadaran mengenai hukum itu sendiri.

Menurut analisis kami apabila ditinjau baik dari hukum islam maupun hukum adat perceraian yang dilakukan oleh suami kepada istri tersebut sudah dianggap cerai karena di dalam kedua hukum tersebut tidak terdapat aturan yang mensyaratkan diharuskannya talak tersebut harus terdapat saksi dan dilakukan di hadapan instansi yang berwenang.

Setelah dua tahun tersebut si istri pun menikah lagi dengan lakilaki lain. Tentunya pernikahan yang kedua ini dilakukan secara sirri atau dengan kata lain pernikahan tersebut tidak sah secara Negara. Pernikahan itu pun secara otomatis tidak bisa dicatatakan karena status si istri dalam Negara masih sah menjadi istri dari suami yang pertama.

Kemudian, menurut analisis kami apabila ditinjau dari hukum adat pernikahan kedua yang dilakukan oleh istri tersebut sudah sah, dikarenakan menurut suku adat di daerah tersebut sudah sesuai dengan adat istiadat yang berlaku di daerah tersebut. Begitupun 
dengan hukum islam, pernikahan kedua tersebut sudah sah dikarenakan telah memenuhi rukun dan syarat-syarat pernikahan.

Kami juga mengutip pendapat KH. Bahruddin salah seorang tokoh agama yang menikahkan pasangan tersebut, menurut beliau bahwa untuk masalah pandangan hukum apabila ditinjau secara yuridis memang tidak sah karena perceraiannya tidak melalui pengadilan dan juga tidak mendapatkan akta cerai yang resmi, namun secara agama itu sah karena menurut informasi bahwa ikrar talak yang dilakukan oleh mantan suaminya adalah dalam keadaan yang sadar dan waras.

Adanya Pengadilan Agama sebagai satu-satunya lembaga yang ditunjuk oleh Negara dalam memeriksa, mengadili dan memutus perkara orang islam diantaranya adalah perceraian, merupakan langkah tepat untuk menghindari dari kewenangan seorang suami terhadap isterinya dengan mudah menjatuhkan talak.

Perceraian memang harus dilakukan hanya di hadapan Pengadilan, karena dalam melakukan perceraian di hadapan sidang, baik pihak suami atau istri yang bercerai tersebut memiliki kepastian hukum terhadap talaknya, sehingga hak-hak akibat talak tersebut bisa dilaksanakan dan diterima dengan utuh oleh pihak yang bercerai. Pengadilan tidak mengenal pengesahan talak di luar Pengadilan, tidak ada proses legalisasi atau itsbat perceraian.

Mengenai sahnya perkawinan dan pencatatan perkawinan terdapat pada Pasal 1 dan 2 Undang-Undang No. 1 Tahun 1974 Tentang Perkawinan, yang berbunyi: "(1) Perkawinan adalah sah, apabila dilakukan menurut hukum masing-masing agamanya dan kepercayaannya itu; (2) Tiap-tiap perkawinan dicatat menurut peraturan perundang-undangan yang berlaku."

Dari ketentuan tersebut, dapat diketahui bahwa sebuah perkawinan adalah sah apabila dilakukan menurut hukum masingmasing agamanya dan kepercayaannya itu. Ini berarti bahwa jika suatu perkawinan telah memenuhi syarat dan rukun nikah atau ijab kabul telah dilaksanakan (bagi umat Islam) atau pendeta/pastur telah melaksanakan pemberkatan atau ritual lainnya, maka perkawinan tersebut adalah sah terutama dimata agama dan kepercayaan masyarakat. Tetapi sahnya perkawinan ini dimata agama dan kepercayaan masyarakat perlu disahkan lagi oleh negara, 
yang dalam hal ini ketentuannya terdapat pada Pasal 2 Ayat (2) Undang-Undang No.1 Tahun 1974 Tentang Perkawinan, tentang pencatatan perkawinan.

Undang-undang Perkawinan menitikberatkan sahnya perkawinan pada dua unsur, yaitu; perkawinan harus dilaksanakan sesuai dengan syarat dan prosedur yang ditentukan oleh UndangUndang (hukum negara) dan hukum agama. Artinya, kalau perkawinan hanya dilangsungkan menurut ketentuan UndangUndang negara tanpa memperhatikan ketentuan-ketentuan agama, perkawinan tersebut tidak sah, demikian juga sebaliknya.25 Poliandri sendiri merupakan bentuk perkawinan yang dilarang dalam ajaran Islam.26 Jika dikaitkan dengan keberadaan lembaga yang telah disediakan oleh pemerintah, maka praktek cerai diluar pengadilan tersebut kurang relevan karena telah adanya pengadilan yang disediakan oleh pemerintah sebagai tempat untuk menyelesaikan permasalahan yang berkaitan dengan proses perceraian suami-isteri.

Berdasarkan Pasal 38 UU No.1 Tahun 1974 Tentang Perkawinan disebutkan bahwa putusnya ikatan perkawinan antara suami-istri disebabkan karena kematian, perceraian, dan keputusan pengadilan. Sedangkan berdasarkan Pasal 114 Kompilasi Hukum Islam (KHI), putusnya ikatan perkawinan karena perceraian dapat diakibatkan karena adanya talak dari suami atau adanya gugatan dari istri. Pasal 114 KHI menyatakan: "Putusnya perkawinan yang disebabkan karena perceraian dapat terjadi karena talak atau berdasarkan gugatan perceraian", bahwa perceraian hanya bisa dilakukan melalui proses sidang di pengadilan, dalam hal ini untuk orang yang beragama Islam di Pengadilan Agama. Pasal 39 ayat (1) UUP menyatakan: "Perceraian hanya dapat dilakukan di depan

25 Wahyono Darmabrata, Tinjauan UU No. 1 Tahun 1974, Jakarta: Gitama Jaya, 2003), hal. 101

26 Mengenai sebab larangan poliandri dalam Islam dapat dilihat secara lebih jelas dalam beberapa literer yakni: Rachmat Ramadhana al-Banjary dan Anas al-Djohan Yahya, Hikmahnya Poligami: Mengapa AA Gym Menikah Lagi? Menangkap Hikmah di Balik Tabir Poligami, (Yogyakarta: Pustaka al-Furqan, 2007), hal. 4-11; Titik Triwulan Tutik, Poligami Perspektif Perikatan Nikah Telah Kontekstual Menurut Hukum Islam dan Undang-Undang Perkawinan Nomor 1 Tahun 1974, (Jakarta: Prestasi Pustakarya, 2007), hal. 55-57. 
sidang Pengadilan setelah Pengadilan yang bersangkutan berusaha dan tidak berhasil mendamaikan".

Perkawinan baru yang dilakukan setelah proses perceraian yang ilegal menurut KHI memiliki status tidak sah dalam konteks KHI. Oleh sebab itu, dari adanya status tidak sahnya perkawinan baru pasca perceraian ilegal tersebut, status anak hasil perkawinan yang baru juga akan terkena dampaknya, yakni menjadi anak yang tidak sah menurut KHI. Hal ini didasarkan pada ketentuan Pasal 99 yang menyatakan bahwa anak yang sah adalah anak yang lahir dalam atau akibat dari perkawinan yang sah. Sehingga karena perkawinan baru pasca perceraian yang ilegal adalah tidak sah menurut KHI, maka status anak yang dihasilkannya juga menjadi tidak sah menurut KHI.

Di dalam hukum yang berlaku di Indonesia yang mengatur tentang perkawinan, tidak diatur dan tidak dikenal pengertian cerai di luar Pengadilan. Talak menurut hukum adalah ikrar suami yang diucapkan di depan sidang Pengadilan Agama. Sedangkan apabila talak dilakukan atau diucapkan di luar pengadilan, maka perceraian sah secara hukum agama saja, tetapi belum sah secara hukum negara karena belum dilakukan di depan sidang Pengadilan Agama. Akibat dari talak yang dilakukan di luar Pengadilan adalah ikatan perkawinan antara suami-istri tersebut belum putus secara hukum, atau dengan kata lain, baik suami atau istri tersebut masih sah tercatat sebagai suami-istri.

Yang paling mendasar sebagai dampak dari talak di luar Pengadilan adalah tidak adanya kepastian hukum untuk perceraiannya, maka dianggap tidak ada perceraian bagi suami istri yang bercerai di luar Pengadilan tersebut karena tidak ada legal formalnya padahal legal formal mengenai perceraian bagi orang Islam itu hanya dikeluarkan oleh Pengadilan Agama dan tidak akan mendapatkan hak apapun bagi suami istri yang melakukan perceraian tersebut. Sehingga, dari ketiadaan hukum secara pasif itulah akan berakibat kepada:

1. Tidak ada kepastian hukum

Bagi keduanya (suami istri) tidak mempunyai kepastian hukum dalam penjatuhan talaknya. Akibat dari tidak ada kepastian hukum tersebut, jika salah satu atau kedua belah pihak ingin menikah kembali dengan orang lain maka pernikahannya 
tidak akan diterima atau tidak sah karena dianggap masih memiliki ikatan perkawinan dengan pasangan sebelumnya.

2. Ada kesewenangan suami terhadap isteri

Jika perceraian tidak dilakukan di Pengadilan, akan menimbulkan kesewenangan suami terhadap isterinya, di antaranya isteri cenderung akan dirugikan karena anggapannya adalah talak termasuk ke dalam haknya suami dan jika hal ini terjadi, maka suami akan melakukan hal yang diinginkan suami semaunya.

3. Akan menimbulkan prioritas suami lebih dari pada isteri

Jika talak dilakukan di luar Pengadilan, maka suami akan mentalak isteri dengan tidak beraturan, karena menganggap talak adalah hak suami. Akibatnya isteri cenderung dirugikan, padahal dalam rumah tangga didasari dengan rasa cinta, kasih, dan saling menjaga keutuhan rumah tangga.

4. Anak

Anak dalam posisi ini bisa diasumsikan akan dirugikan. Karena, dengan bercerainya orang tua anak tersebut, anak harus mendapatkan haknya untuk hidup berkembang dengan mendapatkan pendidikan yang layak dan kebutuhan kehidupan sehari-hari. Namun, jika orang tua anak dimaksud melakukan talak di luar Pengadilan dan kemudian anak tidak mendapatkan haknya, maka tidak bisa mengajukan gugatan ke Pengadilan Agama untuk mendapatkan hak anak tersebut talak yang dilakukan di luar Pengadilan tidak akan mendapatkan legalitas sesuai dengan ketentuan yang berlaku.

5. Harta Bersama

Di dalam pengajuan cerai di Pengadilan baik melalui proses permohonan atau gugatan, harta bersama dijadikan sebagai objek gugatan dan bisa didapatkan oleh kedua belah yang bercerai. Akan tetapi, jika oleh, kedua pihak melakukan talak di luar Pengadilan, maka harta bersama tidak akan bisa digugat, karena yang akan mengeluarkan legalitas adalah Pengadilan Agama.

6. Kewarisan

Waris hanya berasal karena ada kematian diantara anggota keluarga, dan ahli warisnya adalah anggota keluarga yang masih sah masuk ke dalam hubungan perkawinan, sahnya hubungan 
perkawinan bisa dilihat dari legalitas perkawinan tersebut, dan apabila tidak terjadi pemutusan hubungan suami isteri melalui Pengadilan, maka hubungan perkawinan masih memiliki legalitas. Walaupun antara suami isteri telah melakukan talak di luar Pengadilan, hubungan perkawinannya masih sah, sehingga jika salah satu pihak meninggal dunia maka pihak yang lainnya dapat mengajukan gugatan atau permohonan untuk harta warisan yang ditinggalkan, karena dianggap masih dalam hubungan suami isteri yang sah menurut ketentuan yang berlaku.

\section{Penutup}

Perceraian di dalam hukum Indonesia merupakan suatu perkara yang harus di ikrarkan didepan pengadialn. Pengucapan talak dihadapan pengadilan merupakan amanah dari pasal 115 Kompilasi Hukum Islam (KHI) yang berbunyi " Perceraian hanya dapat dilakukan di depan sidang Pengadilan Agama, setelah Pengadilan Agama tersebut berusaha dan tidakberhasil mendamaikan kedua belah pihak." Akan tetapi dalam kenyataanya masih banyak masyarakat Indonesia yang melakukan perceraian tidak didepan pengadilan. Salah satunya perceraian di luar pengadilan yang banyak dilakukan oleh masyarakat di Desa Nyormanis Kecamatan Blega Kabupaten Bangkalan, Madura.

Perbuatan perceraian yang dilakukan diluar Pengadilan Agama oleh masyarakat Desa Nyormanis bertentangan dengan Pasal 38 Undang-Undang No.1 tahun 1974 dan Pasal 114 Kompilasi Hukum Islam (KHI). Perceraian yang dilakukan di luar Pengadilan, pada dasarnya dapat menimbulkan kerugian berupa: Tidak ada kepastian hukum, Ada kesewenangan suami terhadap isteri, Akan menimbulkan prioritas suami lebih dari pada isteri, Harta Bersama, Kewarisan, dan status anak.

\section{Daftar Pustaka}

al-Banjary, Rachmat Ramadhana dan Anas al-Djohan Yahya. Hikmahnya Poligami: Mengapa AA Gym Menikah Lagi?Menangkap Hikmah di Balik Tabir Poligami.Yogyakarta: Pustaka al-Furqan, 2007.

Darmabrata,Wahyono.Tinjauan UU No. 1 Tahun 1974. Jakarta: Gitama Jaya, 2003. 
Effendi, Satria. Problematika Hukum Keluarga Islam Kontemporer. Jakarta: Gramedia, 2004.

Gazaly, Abdul Rahman. Fikih Munakahat. Premena Jaya, 2006.

Hasan, Syaikh Hasan. Fikih Keluarga. Jakarta: Pustaka al-Kautsar, 2006.

Hayati, Vivi. Dampak Yuridis Perceraian di Luar Pengadilan (Penelitian di Kota Langsa), Vol. 10 No. 2 Juli 2015.

Munandar. Skripsi: "Tinjauan Hukum Islam Terbadap Talak Di Luar Pengadilan Agama Pada Masyarakat Di Kecamatan Lappariaja Kabupaten Bone”.Makassar: UIN Alauddin Makassar, 2017.

Sabiq, Sayyid. Fiqh al-Sunnah. Kairo: Maktabah dar al-turas. tth.

Subekti. Pokok-pokok Hukum Perdata. Jakarta: PT. Intermasa, 2010.

Tihami, M.A dan Sohari Sahran. Fikih Munakahat Kajian Fikih Nikah. Jakarta: Rajawali Pers, 2009.

Tutik, Titik Triwulan. Poligami Perspektif Perikatan Nikah Telah Kontekstual Menurut Hukum Islam dan Undang-Undang Perkawinan Nomor 1 Tahun1974, Jakarta: Prestasi Pustakarya, 2007.

Departemen Pendidikan dan Kebudayaan. Kamus Besar Bahasa Indonesia.

Undang-undang No. 1 Tahun 1974 tentang Perkawinan

Tim Redaksi Nuansa Aulia. Kompilasi Hukum Islam. Bandung: Nuansa Aulia, 2008.

Peraturan Pemerintah No. 9 tahun 1975. 